\title{
TRANSFORMATION OF THE VALUE OF PARENTING IN MODERN SOCIETY
}

\author{
Natalia Umanets ${ }^{1}$ \\ Lviv Polytechnic National University, Lviv, Ukraine \\ ${ }^{1}$ senior teacher of Department of Sociology and Social Work
}

Background: Transformation of all aspects of economic and social life that has started at the beginning of 20th Century touched upon family structures and relations as well. Nowadays, the problems of family and parenting values acquire the special actuality, family institution experiences a crisis the area of child-paternal mutual relations, so called "parental alienation" characterized by weakening of social contacts between parents and children. Reality of modern Ukrainian society testifies to the parenting crisis and absence of effective actions from the community and the Government to overcome this crisis.

Purpose: Based on analysis of the structural changes of the family in modern society to research reasons for the transformation of the value of parenting.

Methods: For and method of the decision of the put research tasks in-process there were the used methods structurally functional to the analysis, comparative generalization and systematization.

Results: There are numerous research works and studies by domestic and foreign scientists that are dedicated to different aspects of parenting and its values. Presently a study of parenting is a direction in sociology that is actively being formed in Ukraine. The major attributes of parenting as a social phenomena, are relations and interactions, and also self -awareness as a parent. Parenting can be classified as a subsystem in the structure of family and its function. However, at the modern stage of development of the society there is an increase in-differentiation of these two social phenomes. Processes of formation of young families now in place in most embodiments, complex and contradictory conditions that are characterized by changes in social relations and the emergence of new values.

Conclusion: The understanding of the transformation of the value of parenting could be viewed as a change of parenting practices: responsible family planning, having the first child later in more mature age, conscious choice of institutes for socialization and child's education, active involvement of both parents in education process.

Keywords: parenting, family, society, family values, values, marriage, transformation, youth.

Трансформація всіх сфер життєдіяльності, яка почалася ще на початку XX ст. торкнулася й сімейно-шлюбних структур та відносин. В сучасних умовах ці трансформаційні процеси посилюються під впливом глобалізації, що спричиняє переоцінку базових культурних цінностей та цінностей інституційного порядку в пострадянському суспільстві. Проблеми сім'ї і цінності батьківства в наш час набувають особливої актуальності, з огляду на те, що сам інститут сім'ї переживає кризу, яка виявляється й в сфері дитячо-батьківських взаємин, у тому числі в ослабленні соціальних зв'язків між батьками та дітьми, зростанні внутрішньосімейної конфліктності й агресії, зниженні якості родинного виховання, інфантилізації молодих батьків та зниженні відповідальності батьків за своїх дітей.

Реальність сучасного українського суспільства свідчить про кризу батьківства та відсутність ефективних дій з боку громадськості, уряду по іiі подоланню. Так, робота, що інтенсивно проводиться в країні із збільшення народжуваності поєднується з відсутністю цілеспрямованої, грамотно вибудованої педагогічної підготовки майбутніх батьків до відповідального виконання батьківських обов'язків. Любов, що батьки проявляють до дітей часто поєднується із батьківською неграмотністю, інфантильністю, невмінням вибудовувати повноцінні взаємини 3 дітьми. Батьки, щоб не завантажувати себе часто перекладають виховні обов'язки на заклади освіти, а спілкування на прабатьківські структури. В результаті цього руйнуються внутрішньо сімейні стосунки, втрачається контроль над дітьми, порушується процес соціалізації. Виходячи 3 цього, очевидною $є$ потреба формування ціннісного та свідомого ставлення до батьківства у сучасної молоді. 
Мета: На основі аналізу структурних змін сім'ї в сучасному суспільстві дослідити причини трансформації цінності батьківства.

Для розв'язання поставлених дослідницьких завдань у роботі були використані методи структурно-функціонального аналізу, порівняльний та метод узагальнення і систематизації.

Дослідженню різних аспектів батьківства та його цінностей присвячена ціла низка робіт вітчизняних і зарубіжних вчених. Впродовж XX ст. дослідженнями трансформацій сім'ї займалися учені, серед яких слід виділити роботи П.Сорокіна, У.Огборна, К.Циммермана, Е.Берджесса, Т. Парсонса, Е. Гідденса, М. Мацковського, А.Харчева, А Антонова, С.Голода, Л.Сохань, Н.Бабенко М. Лукашевича та ін.

Питання, пов'язані з впливом дитячо-батьківських стосунків на формування особистості дитини, отримали розробку в дослідженнях як вітчизняних, так і зарубіжних учених (А.Маслоу, К. Роджерс, В. Сатир, В.Столін, Е. Ейдемілер). Проблема психологічної готовності до батьківства представлена в працях А. Адлера, А.Антонова, О.Антоновича, Е.Берна, А.Варги, Р.Овчарової,

3 точки зору культурно-антропологічного підходу феномен батьківства вивчають Р.Бенедикт, А. Інкельс, А. Кардінер, Р. Ліптон, М. Мід, Л.Філіппова.

В рамках соціологічного знання батьківство розглядається як соціальний інститут, що знайшло віддзеркалення в працях А.І. Антонова, С.Голода, Т.Гурко, О. Стрельник, Л.Слюсар. А от В.Медков, А.Синельніков, П. Сорокін, В.Думанська розглядають батьківство як соціально значиму функцію сім'ї. Таким чином, можемо відзначити, що феномен батьківства в контексті розгляду окремих соціокультурних процесів $є$ представленим в науковій літературі. Проте мало дослідженим залишається ряд теоретичних і практичних проблем вивчення цінності батьківства, чинників його трансформації, механізмів формування і перспектив розвитку в сучасній Україні.

Т.А. Гурко в середині 1990-х рр. виділила батьківство як окрему галузь соціології (Гурко, 2012). В даний час вивчення батьківства $є$ напрямом соціології, що активно формується в Україні (О.Стрельник, Л.Слюсар,I. Курило, А.Корман). Проблеми батьківства досліджуються у зв'язку з процесами трансформації сімейно - шлюбних взаємин на тлі глобалізаційних процесів.

Батьківство - це соціальний феномен, найважливішими атрибутами якого є стосунки $\mathrm{i}$ взаємодії, а також усвідомлення себе як батька. Здійснюючи аналіз феномену батьківства, потрібно розглянути питання про його зв'язок 3 сімейною проблематикою. Традиційне визначення сім'ї, яке дає А.Антонов, передбачає наявність трьох типів стосунків - шлюбу, батьківства, родинності (Антонов, 1996, с.66). В історичному/традиційному розумінні сім'я $\epsilon$ певною системою взаємин між подружжям-батьками і дітьми. У цьому контексті батьківство можна розглядати як підсистему в структурі сім'ї та їі функцію. Але на сучасному етапі розвитку суспільства все більше спостерігається розмежування цих двох соціальних феноменів, й воно посилюється. 3 одного боку, сучасна сім'я далеко не завжди 3 обов'язковістю передбачає батьківство, з іншого - батьківство в сучасному суспільстві отримало санкцію на самостійне виконання своїх функцій незалежно від офіційно оформлених родинних стосунків.

Сучасне батьківство виходить за своєю значимістю і функціональністю за рамки суто фамілістичних стосунків. Батьківство активно взаємодіє з соціальними інститутами: освітою, охороною здоров'я, інститутами соціальної допомоги і підтримки громадян. Воно має на увазі не лише ідентичність «реальних» батьків і матерів, але і погляди, що обумовлюють ставлення дорослих до дітей в цілому, тісно пов'язані з рівнем культури, громадянською самосвідомістю.

Можна виділити три групи родинних цінностей: цінності, пов'язані $з$ шлюбом, батьківством і спорідненістю. Серед родинних цінностей провідною цінністю є цінність батьківства. До цінностей батьківства відносяться цінність дітей (багатодітність/малодітність), цінність соціалізації і виховання, цінність спілкування. Цінність батьківства знаходить своє віддзеркалення в батьківських відчуттях, взаєминах 3 дітьми, соціальних ролях, соціальному статусі батьків. Батьківство виконує функції соціалізації, збереження гармонійних родинних стосунків, благополуччя і культури в соціумі. Отже цінності батьківства - це обумовлене історичними й культурними чинниками відношення до дітей через виконання батьками 
батьківських ролей, що забезпечують їх народження, соціалізацію та виховання. Таким чином цінність батьківства можна охарактеризувати:

- усвідомленою готовністю до народження дітей;

- установкою на народження здорових нащадків;

- добросовісним виконанням батьківських обов'язків;

- моральною і правовою відповідальністю за майбутнє своїх дітей;

- високим рівнем соціальної відповідальності;

- знанням родинних традицій, культурних цінностей.

Трансформація функціонування сім'ї, поява в ії життєдіяльності дисфункцій об'єктивно знижує цінність батьківства в системі родинних цінностей. Діти перестали бути цінністю, формою самопожертвування, засобом забезпечення старості батьків, вони, навпаки, на сучасному етапі розвитку суспільства вимагають величезних вкладень та витрат. 3. Бауман, звертаючи увагу на відмінність користі і цінності, вказував, що користь означає вигоду для себе, «цінність» передбачає самопожертвування, тобто цінувати означає віддавати[Бауман, 3. (2002), c.208]. Отже можна сказати, що саме народження і виховання дітей якнайповніше відповідає дефініції «дійсна цінність».

Трансформація цінностей батьківства розуміється як зміна поведінкових ресурсів батьків, батьківських практик у відношенні до дітей. Трансформація батьківських практик передбачає зміну їх цілей, які здійснюють вплив й на цінність самого батьківства. Одним з показників, що свідчить про трансформацію цінності батьківства, $є$ доля простого відтворення населення на одну сім'ю. За даними статистики ця доля повинна в середньому складати 2,15 дитини. На рубежі XX-XXI ст. цей показник дорівнював у США - 1,5; у Західній Свропі - 1,1; в Україні 1,12 (1999 р.) і 1,5 (2015 р.), 1,3 (2018) (Стат. зб, 2018, с.9). 3 кінця ХХ століття активно починають поширюватися серед населення установки на малодітність, що посилилися на сучасному етапі.

Можна виділити чинники, що детермінують процес трансформації цінності батьківства. Їх можна розглянути в межах модерністської та кризової парадигм. В рамках модерністської парадигми основною причиною трансформації цінності батьківства стає криза сім'ї, яка спричинена такими мікросоціальними явищами як індустріалізація, урбанізація, емансипація. I криза розуміється як еволюційні зміни сім'ї і родинних цінностей. Ці зміни направлені на егалітаризацію, демократизацію та нуклеарізацію інституту сім'ї. Процеси, що відбуваються у сфері шлюбно-сімейних взаємин, розглядаються як позитивні, що є об'єктивно спричиненими сучасним розвитком суспільства. Саме цей розвиток вимагає переходу до нових форм родинних стосунків, а криза сім'ї пояснюється незавершеністю процесу переходу від традиційних/патріархальних форм сім'ї до сучасних (С.Голод, Т.Гурко, О.Стрельник). Дана концепція заснована на ідеї свободи вибору родинних цінностей, цінностей батьківства, принципі «суверенності сім'ї».

Представники кризисної парадигми нестабільність сучасного суспільства пояснюють кризою сім'ї, родинних цінностей, невиконанням нею функцій відтворення і соціалізації дітей, виникненням нових родинних цінностей, заснованих на індивідуалізмі, прагненні до матеріального добробуту, кар'єрного зростання (А.Антонов, А.Синельніков, О.Вишневський). Представники цього напряму вихід 3 кризи бачать у формуванні нових та переорієнтації традиційних родинних цінностей на противагу індивідуальним цінностям відповідно до нових умов сучасного суспільства, формуванні нових пріоритетів сімейної політики, яка б сприяла ії зміцненню.

Трансформація цінності сім'ї, поява нових типів сімей робить вплив і на трансформацію цінності батьківства як основоположної родинної цінності. Можна говорити про особливості змін цінностей батьківства на кожному історичному етапі трансформації сім'ї:

- на першому етапі трансформації сім'ї (аграрне суспільство/ традиційна сім'я, в якій діти розглядаються як застава благополучної старості) - акцент робився на багатодітність (багато дітей, репродуктивний цикл використовувався повністю), 
обмежувалося штучне переривання вагітності. Існувало негативне ставлення до сімей, що не мають дітей;

- на другому етапі (індустріальне суспільство, основою є капітал) - продовжують переважати цінності родинності над індивідуалізмом. Сім'я орієнтована на середньодітність (три - чотири дитини);

- на третьому етапі ( постіндустріальне суспільство,орієнтоване на дітоцентристську сім'ю) - цінність батьківства виявляється в свідомому плануванні дітей, здійснюється свідоме культивування вкладень в майбутнє дітей,. починає формуватися часткова перевага цінностей індивідуалізму над цінностями родинності. Нормою стає малодітність (одна/дві дитини);

- на четвертому етапі (мережеве суспільство) трансформації інституту сім'ї виникає повне переважання індивідуалізму, вибір відносно типу сім'ї робить сама особистість, існує орієнтація на малодітність та починає формуватися масова добровільна бездітність(childfree).

В умовах постіндустріального суспільства виникають варіативні типи родинних стосунків, $\mathrm{i}$ характерним для них є прагнення до професійного і кар'єрного зростання, відсутність орієнтації на дітей. Виникає нова парадигма взаємин дітей і батьків, основним принципом якої стає принцип децентризму. На думку Е. Гідденса, основа шлюбу в постіндустріальних суспільствах - це не економіка, а «інтимність, сексуальність і емоції», які є непостійними. Але якщо щлюб не $\epsilon$ економічним союзом і не створюється заради народження дітей, то він не може зберігатися довго, а тому не потребує інституціоналізації. втрачає значення формального інституту, який безпосередньо пов'язаний з контролем над сексуальністю та дітонародженням і підтримується чіткими правилами гендерного розподілу праці, традицією. I він уже не є єдиною легітимною формою організації інтимності (Гідденс, 2004, с. 36).

В умовах сучасного суспільства змінюється ставлення до цінності батьківства. Створення сім'ї, виконання ролі батьків не є значимою цінністю: батьківська роль відкладається, людина прагне здобути освіту, добитися кар'єрного зростання, самореалізації,особистої автономії, матеріального благополуччя. Відсутність потреби в дітях, орієнтація на малодітність пояснюються як економічними, так і соціальними причинами. Сучасні люди, існуючи у суспільстві споживання, пов'язують задоволеність життям з високим рівнем матеріального добробуту. Тому престиж багатодітної сім'ї не $\epsilon$ привабливим. В умовах економічної нестабільності, соціальної напруженості, посиленні соціальної диференціації це можна пояснити страхом не забезпечити дітям гідний рівень життя, не дати відповідної освіти. Формування нового ставлення до цінності батьківства пов'язане ще 3 можливістю великої свободою вибору своєї життєвої стратегії, яка є наслідком демократизації суспільства, соціальної мобільності, руйнування традиційних норм і цінностей, у тому числі і родинних цінностей. На зміну традиційній парадигмі, заснованій на жорсткому авторитеті старшого покоління, певних стандартах поведінки, приходить парадигма інноваційна, особистісно орієнтована, яка дозволяє людині самостійно виробляти родинні цінності, варіативні моделі батьківських практик.

Висновки: Отже, трансформацію цінності батьківства ми розуміємо як зміну батьківських практик (відповідальний підхід до планування сім'ї, пізніший вік народження першої дитини, свідомий вибір інститутів соціалізації і виховання дітей, активне залучення обох батьків у виховний процес). До чинників, що детермінують трансформацію цінності батьківства в сучасному суспільстві можна віднести глобальні, соціально-політичні, соціокультурні. Глобальні чинники: демографічний перехід, становлення постіндустріального суспільства, зміна ролі жінки (поєднання нею професійних і сімейних обов'язків), перетворення освіти на вирішальний чинник суспільного і особистого розвитку, формування постматеріалістичних цінностей, орієнтація на малодітність, високу якість життя, професійну кар'єру, зростання мобільності сучасної людини. Соціально-політичні чинники:становлення соціальної держави орієнтація на свободу особи, розповсюдження різних асоціальних форм поведінки в суспільстві, поява девіантного батьківства, зміна демографічної поведінки, , зниження 
виховного потенціалу сім'ї, зростання соціального сирітства. Соціокультурні чинники: перехід від традиційної форми сім'ї до сучасних типів сімейних стосунків, вплив споживацької культури на формування особистості, орієнтація сучасної сімейної культури на незалежність і свободу, трансформація культурних символів і зразків.

\section{References}

Antonov, A. (1996). Sotsiologiya semyi [Sociology of family]. Moskva:MGU (in Russian).

Bauman Z. (2002). Yndyvydualyzyrovannoe obshchestvo. Moskva: Logos (in Russian)

Hurko,T.(2008) Brak y rodytelstvo v Rossyy. M.: In-t sots. RAN [Elektronnyi resurs] https://www.isras.ru/files/File/Publication/Brak_i_roditelstvo_Gurko_2008.pdf (2020,13.04.)

Giddens, A. (2004). Transformatsiya intimnosti. Seksualnost, lyubov i erotizm v sovremennykh obshchestvakh [Transformation of intimacy. Sexuality, love and eroticism in modern societies]. Moscow; St. Petersburg: Piter Publ. (in Russian)

Tablytsi narodzhuvanosti, smertnosti ta serednoi ochikuvanoi tryvalosti zhyttia za 2018 rik.(2019) Statystychnyi zbirnyk. [Elektronnyi resurs] http://ukrstat.gov.ua/druk/publicat/kat_u/2019/zb/08/zb_tabl_nar_2018.pdf(2020,13.04.)

\section{Список використаних джерел}

Антонов, А., Медков, В. (1996) Социология семьи. М.:Изд-во МГУ

Бауман, 3. (2002) Индивидуализированное общество / Пер. с англ.М.: Логос

Гурко,Т.(2008) Брак и родительство в России. М.: Ин-т соц.РАН [Електронний ресурс] https://www.isras.ru/files/File/Publication/Brak_i_roditelstvo_Gurko_2008.pdf (2020,13.04.)

Гидденс, Э.(2004) Трансформация интимности. Сексуальность, любовь и эротизм в современных обществах / Пер. с англ. СПб: Питер.

Таблиці народжуваності, смертності та середньої очікуваної тривалості життя за 2018 рік.(2019) Статистичнй $\quad$ збірник. [Електронний http://ukrstat.gov.ua/druk/publicat/kat_u/2019/zb/08/zb tabl_nar_2018.pdf(2020,13.04.)

\section{Contact information:}

Уманець Наталія Анатоліївна

Natalia.11@ukr.net 